\title{
Parasites of two coexisting invasive sailfin catfishes (Siluriformes: Loricariidae) in a tropical region of Mexico
}

\author{
María Amparo Rodríguez-Santiago, Luis García-Prieto², Berenit Mendoza-Garfias², \\ David González-Solís ${ }^{3}$, and Mayra I. Grano-Maldonado ${ }^{4}$
}

\begin{abstract}
Currently many species of Amazon sailfin catfishes (Loricariidae) have been introduced to wild environments outside their native range. There is, however, little knowledge about their role as vectors of parasites that can infect native fish or even humans through its consumption. The aim of the present study was to determine the parasitic fauna of the invasive sailfin catfish species Pterygoplichthys pardalis (leopard pleco) and P. disjunctivus (vermiculated pleco) from freshwater systems in the southeast of Mexico. Four ectoparasite species were found in P. pardalis (1 protozoan: Ichthyophthirius multifiliis; 2 monogeneans: Urocleidoides vaginoclastrum and Heteropriapulus heterotylus; 1 digenean: Clinostomum sp.), and only one in Heteropriapulus disjunctivus (H. heterotylus). No endoparasites were found. Ichthyophthirius multifiliis, U. vaginoclaustrum and Clinostomum sp., were considered as rare species (prevalence $<5 \%$ ) since they were found in a single individual of P. pardalis. H. heterotylus was the only species shared among both host species and it occurs throughout the year. This monogenean species represents $96 \%$ of total parasites recorded in P. pardalis and $100 \%$ in P. disjunctivus. Monthly values of prevalence, intensity and abundance of $H$. heterotylus in both host species showed important intra-annual variations, but not differ significantly between both hosts.
\end{abstract}

Actualmente muchas especies de peces conocidos como plecos o peces diablo (Loricariidae) han sido introducidas en ambientes silvestres fuera de su área de distribución natural. Sin embargo, hay poco conocimiento acerca de su papel como vectores de parásitos que puedan infectar a los peces nativos o incluso los seres humanos a través de su consumo. El objetivo del presente estudio fue determinar la fauna parasitaria de las especies de plecos Pterygoplichthys pardalis (pleco leopardo) y P. disjunctivus (pleco vermiculado) en sistemas de agua dulce del sureste de México. Fueron encontradas cuatro especies de ectoparásitos en P. pardalis (1 protozoario: Ichthyophthirius multifiliis; 2 monogeneos: Urocleidoides vaginoclastrum y Heteropriapulus heterotylus; 1 digeneo: Clinostomum sp.) y una en P. disjunctivus (H. heterotylus). No se encontraron endoparásitos. Ichthyophthirius multifiliis, U. vaginoclaustrum y Clinostomum sp. fueron consideradas como especies raras (prevalencia $<5 \%$ ), ya que estuvieron en un solo individuo de $P$. pardalis. Heteropriapulus heterotylus fue la única especie compartida entre ambas especies de peces y que estuvo presente durante todo el año, y representó el $96 \%$ del total de parásitos registrados en $P$. pardalis y el $100 \%$ en $P$. disjunctivus. La prevalencia, intensidad media y abundancia media de H. heterotylus mostraron importantes variaciones intra-anuales en ambas especies de peces, pero no difirió significativamente entre ambos hospederos.

Key Words: Exotic fish, Parasitic fauna, Campeche, Leopard pleco, Vermiculated pleco.

\section{Introduction}

Introduction of non-native fish species threatens native biodiversity and the ecosystem function of aquatic communities globally (Kelly et al., 2009; Cucherousset \& Olden, 2011). Many non-native fish species may become predators, competitors (Hill \& Lodge, 1999), or even spread parasites or pathogens to native species (Torchin et al., 2003; Torchin \& Mitchell, 2004). The latter has been the subject of concern for many decades, since it is well known that parasites transmitted by non-native species can cause severe impacts on native species (Bakke et al., 1990; Poulin et al., 2011).

Amazon sailfin catfishes, also known as "armored catfishes", are endemic to freshwater ecosystems of South and Central America and some species have recently been reported in wild environments outside their native range (e.g. North America: Fuller et al., 1999; Capps, 2008; Gibbs et al., 2008; Pound et al., 2011; Puerto Rico: Bunkled-Williams et al., 1994; México: Guzmán \& Barragán, 1997; Wakida-

\footnotetext{
${ }^{1}$ CONACYT, Universidad Autónoma del Carmen, Facultad de Ciencias Naturales, Centro de Investigación de Ciencias Ambientales, Av. Laguna de Términos s/n Col. Renovación 2da Sección, C.P. 24155 Ciudad del Carmen, Campeche, Mexico. marodriguezsa@conacyt. mx, amparoshalom@hotmail.com (corresponding author)

${ }^{2}$ Instituto de Biología, Universidad Nacional Autónoma de México, A.P. 70-153, C.P. 04510, México, D.F., Mexico

${ }^{3}$ El Colegio de la Frontera Sur, Unidad Chetumal, Avenida Centenario Km. 5.5, C.P. 77900, Chetumal, Quintana Roo, Mexico. dgonzale@ecosur.mx ${ }^{4}$ Departamento de Ecofisiología, Facultad de Ciencias del Mar, Universidad Autónoma de Sinaloa. Paseo Claussen S/N, Col. Centro, C.P. 82000, Mazatlán, Sinaloa, Mexico.grano_mayra@hotmail.com
} 
Kusunoki et al., 2007; Wakida-Kusunoki \& Amador-del Ángel, 2011; Taiwan: Liang et al., 2005, 2006; Philippines: Chavez et al., 2006; Turkey: Özdilek, 2007; Poland: Keszka et al., 2008; Vietnam: Levin et al., 2008; Java and Australia: Capps, 2008; Bangladesh: Hossain et al., 2008; Italy: Piazzini et al., 2010; Serbia: Simonović et al., 2010 and Tailand: Chaichana \& Jongphadungkiet, 2012). It has been suggested that in most of those recipient areas recorded so far, aquarists were assigned responsibility for releasing the catfishes into natural ecosystems and the their subsequent establishment (Simonović et al., 2010).

The first report of a wild sailfin catfish in Mexico was made by Guzmán \& Barragán (1997) in the Mezcala River, Guerrero. More recently, Wakida-Kusunoki et al. (2007) reported the presence of Pterygoplichthys disjunctivus (Weber, 1991) and P. pardalis (Castelnau, 1855) in freshwater ecosystems of southeastern Mexico. Currently, these species are listed as one of the most invasive species in Mexico (Mendoza-Alfaro et al., 2011) and continue spreading and proliferating massively throughout rivers, streams, reservoirs and lakes of several parts of the country. The main problem caused by these species is the competition for space and food with native fish species, including those commercially important (Martínez-Palacios et al., 2009; Sandoval-Huerta et al., 2012). However, nowadays there is little information available about their parasitic fauna (Mendoza-Franco et al., 2012) and the role of these parasite species as potential pathogens to native fish species or humans (Pound et al., 2011).

Therefore, the aims of this study were (1) to determine the parasitic fauna of the invasive sailfin catfish species: $P$. pardalis and $P$. disjunctivus from riverine systems of southeastern Mexico, (2) to compare the population parameters of infection (prevalence, intensity and abundance) among these coexisting fish hosts and (3) to determine whether the intra-annual variability in the prevalence, mean intensity and mean abundance of parasites in each fish species is related to seasonal changes in water temperature and/or to the host size and weight.

\section{Material and Methods}

Study area and sampling method. Specimens of the leopard pleco Pterygoplichthys pardalis and the vermiculated pleco $P$. disjunctivus were collected from two localities in the Palizada River (Santa Gertrudis: $18^{\circ} 20^{\prime} 04.7^{\prime}$ N, 91 41'56.1'W and La Rivera: $\left.18^{\circ} 20^{\prime} 01^{\prime \prime} \mathrm{N}, 91^{\circ} 41^{\prime} 55^{\prime \prime} \mathrm{W}\right)$ within the Natural Protected Area Laguna de Terminos, Campeche, Mexico.

Fish were caught using a casting net $($ mesh $=76 \mathrm{~mm})$ at depths between $0.7 \mathrm{~m}$ to $2.0 \mathrm{~m}$ depth (from January to December 2012) and transported alive (individually) to the laboratory in plastic containers. At each sampling site, the bottom water temperature was recorded by using a multiparameter sensor (YSI-30 Salinity, Conductivity Temperature, Ohio 45387 USA). During the study period (January-December 2012) the average water temperature ranged from $24^{\circ} \mathrm{C}$ (in February) to $30.8^{\circ} \mathrm{C}$ (in August) (Fig. 1b). Fish were sacrificed by decapitation to ensure a fast dead, which is according to Mexican laws (NOM-033-ZOO-1995). The total length $(\mathrm{cm})$ and weight $(\mathrm{g})$ were recorded for each fish. The parasitological survey included the revision of external (eyes, fins, skin, and gill cavities) and internal organs (intestinal caeca, coelomic cavity, stomach, intestine, spleen, gallbladder, liver, kidneys, and heart) and muscle. Internal organs were individually separated and subsequently examined by compression between two $10 \times 10 \times 1.0 \mathrm{~cm}$ flat glasses (Guzmán-Cornejo et al., 2012). Parasites were isolated and preserved in labelled vials with $96 \%$ alcohol.

Identification of monogeneans was based on the characteristics of the sclerotized hard parts of haptor and male copulatory organ. Haptors were subjected to a partial digestion using a proteinase K- base method following Harris et al. (1999) in order to study haptoral sclerites. Trematodes were stained with Gomori's trichrome or Mayer's carmine to determine the internal features. Skin and gills smears were made in search of protozoans, which were impregnated with silver nitrate (Martorelli et al., 2008). Voucher specimens of helminths were deposited at the Colección Nacional de Helmintos, Instituto de Biología, Universidad Nacional Autónoma de México (Mexico).

Data analyses. Prevalence, intensity and abundance were determined as recommended by Bush et al. (1997). Assumptions of normality and homocedasticity in each variable were previously tested by Kolmogorov-Smirnov's and Bartlett's tests, respectively (Sokal \& Rohlf, 1995). To assess significant variations in the overall abundance of parasites over the year, a non-parametric Analysis of Variance of Kruskal-Wallis was used (Steel \& Torrie, 1986). Chi-square tests were used to compare the prevalence and intensity between both host species (Rózsa et al., 2000). Moreover, a Mann-Whitney U-test was used to assess significant differences in the abundance of parasites between hosts (Zar, 1999). Spearman rank correlation analyses were used to assess significant relationships between the population descriptors of parasites (prevalence, intensity and abundance) and fish host size and weight, and water temperature. For these analyzes, the average monthly values were used. $P$-values less than 0.05 were considered significant.

\section{Results}

Species composition and population descriptors of parasites. A total of 223 specimens of the two species of sailfin catfish were collected: 94 vermiculated pleco (total length 18-48 cm, weight 94-506 g) and 129 leopard pleco (total length 17-49 cm, weight 75-512 g). From the total fish individuals, 148 (66\%; 79 Pterygoplichthys pardalis and 69 Pterygoplichthys disjunctivus) were infected with at least one parasite species.

Four parasitic species were found in $P$. pardalis (2 monogeneans: Urocleidoides vaginoclastrum Jogunoori, Kritsky and Venkatanarasaiah 2004 and Heteropriapulus 
heterotylus Jogunoori, Kritsky \& Venkatanarasaiah, 2004, 1 protozoan: Ichthyophthirius multifiliis Fouquet 1876, and 1 trematode: Clinostomum sp.); whereas only one occurred in P. disjunctivus (Heteropriapulus heterotylus). H. heterotylus, $U$. vaginoclastrum and I. multifiliis were found on gill arches and the trematode Clinostomum sp. was found encysted on the base of rays of caudal fin. In both host fish species, internal organs did not present parasites. In P. pardalis, 436 individual parasites were collected of which 408 (96\%) were Heteropriapulus heterotylus; 23 (3.5\%) I. multifiliis; $3(0.5 \%)$ U. vaginoclastrum and $2(0.3 \%)$ Clinostomum sp. On the other hand, $196(100 \%)$ individuals of H. heterotylus occurred in P. disjunctivus (Table 1).

In both sailfin catfish species, the monogenean $H$. heterotylus exhibited a relatively higher prevalence (monthly prevalence values ranged from $23.8 \%-95.5 \%$ in $P$. pardalis and $100 \%$ in $P$. disjunctivus) followed by $U$. vaginoclastrum (4.7\%), Clinostomum sp. (4.7\%) and I. multifiliis (4.5\%). Prevalence values of $H$. heterotylus did not vary significantly (Chi square test, $p>0.05$ ) between samples of $P$. pardalis and $P$. disjunctivus.

Heteropriapulus heterotylus showed also the highest mean intensity $( \pm \mathrm{SE})(3.26 \pm 1.44)$, and did not show a significant difference (Chi square test, $p>0.05$ ) between P. pardalis (1.0 $\pm 0.0-8.9 \pm 1.5$ in) and $P$. disjunctivus $(1.0 \pm 0.0-4.6 \pm 0.4)$. $H$. heterotylus was the most abundant parasite (until $4.65 \pm$ 1.01 ind.host $^{-1}$ in $P$. pardalis and $4.5 \pm 0.39$ ind.host $^{-1}$ in $P$. disjunctivus). The mean abundance of the monogenean $(H$. heterotylus) was not significantly different (Mann Whitney U-test, $p>0.0 .5$ ) between both sailfin catfish species.

Temporal changes in prevalence, intensity and abundance were analyzed only in the monogenean $H$. heterotylus since this was the only species present during the whole year in both fish species (Fig. 1). In P. pardalis, the highest proportion of hosts infected with this parasite was recorded in June (93\%) and the lowest in March (24\%), where as in P. disjunctivus the highest values were in April and November (100\%) and did not show any parasites in December (Fig. 1a). Moreover, in P. pardalis, the intensity of infection by this monogenean was relatively higher between June and September (6.5 \pm 1.0 and $8.9 \pm 1.5$, respectively) and lower in January $(1.0 \pm 0.0)$.
In $P$. disjunctivus, the intensity was also higher between June and September ( $4.5 \pm 0.7$ and $4.6 \pm 0.4$, respectively) (Fig. 1b). Similarly, the abundance of $H$. heterotylus is higher between June and September $\left(3.5 \pm 0.9\right.$ ind.host $^{-1}$ and $4.7 \pm 1.0$ ind. host $\left.^{-1}\right)$ and the lowest in January $\left(0.2 \pm 0.1\right.$ ind.host $\left.^{-1}\right)$ (Fig. 1c).
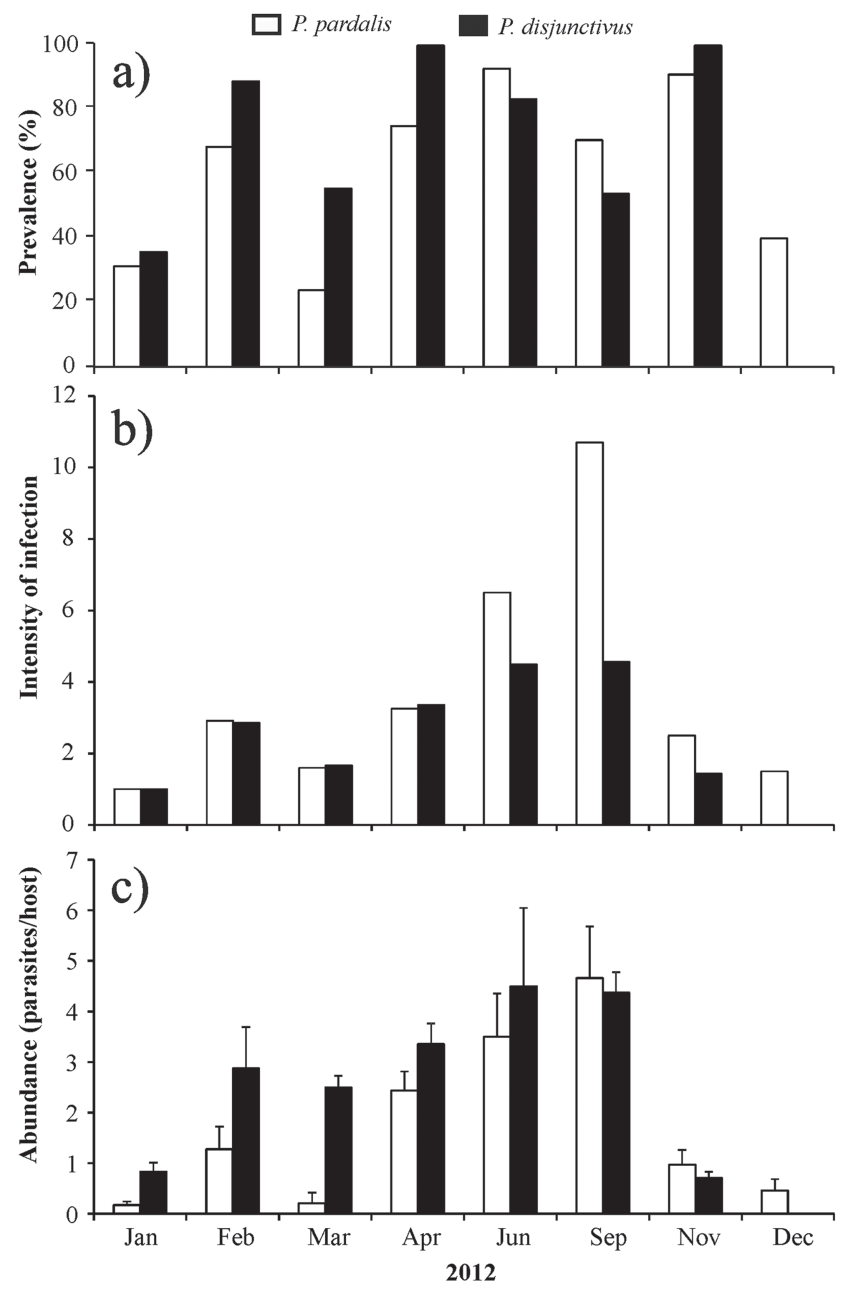

Fig.1. Intra-annual variations in: a) prevalence, b) intensity of infection and c) abundance of parasites in the invasive loricarids Pterygoplichthys disjunctivus and P. pardalis from a freshwater ecosystem of southeastern Mexico.

Table 1. Infection parameters of the parasite from Pterygoplichthys pardalis and P. disjunctivus.

\begin{tabular}{|c|c|c|c|c|}
\hline Parasites & Site of infection & Prevalence $(\%)$ & Mean abundance & Mean intensity \\
\hline \multicolumn{5}{|c|}{ Pterygoplichthys pardalis } \\
\hline \multicolumn{5}{|l|}{ Protozoa } \\
\hline \multicolumn{5}{|l|}{ Monogenea } \\
\hline Heteropriapulus heterotylus & Gill & 62 & $1.59 \pm 1.20$ & $3.26 \pm 1.44$ \\
\hline \multicolumn{5}{|l|}{ Trematoda } \\
\hline Clinostomum sp. & Caudal fin & 1 & $0.01 \pm 0.01$ & $0.26 \pm 0.28$ \\
\hline \multicolumn{5}{|c|}{ Pterygoplichthys disjunctivus } \\
\hline Monogenea & & & & \\
\hline Heteropriapulus heterotylus & Gill & 65 & $1.20 \pm 0.42$ & $2.16 \pm 0.69$ \\
\hline
\end{tabular}


Likewise, it was found that the abundance of this parasite in P. pardalis and P. disjunctivus showed significant variations (Kruskal-Wallis ANOVA, $p<0.01$ ) over the year and was positively correlated with water temperature $\left(\mathrm{r}_{\mathrm{s}}=\right.$ $0.89, p<0.01$ and $\mathrm{r}_{\mathrm{s}}=0.79, p<0.05$, respectively), which ranged from $24^{\circ} \mathrm{C}$ (in February) to $30.8^{\circ} \mathrm{C}$ (in August). A significant correlation was also found between the intensity of $H$. heterotylus (in both fish hosts) and water temperature (P. pardalis, $\mathrm{r}_{\mathrm{s}}=0.91, p<0.01 ;$ P. disjunctivus, $\mathrm{r}_{\mathrm{s}}=0.89$, $p<0.01)$. Moreover, no significant correlations were found between the host size, weight, and infection parameters (abundance, prevalence and intensity).

\section{Discussion}

There was scarce information about the parasitic fauna in the senon-native fish species, especially in the leopard pleco and the vermiculated pleco around the world. Only two parasitological reports have been published in Pterygoplichthys pardalis from its native range (Central Amazonia, Brazil), where a total of 6 helminth species were found: Megacoelium spinicavum (Thatcher \& Varella, 1981), Austrodiplostomum compactum, Diplostomum sp., Gorytocephalus sp., Heteropriapulus sp. and Unilatus sp. (Porto et al., 2012). Whereas outside its native range only Heteropriapulus sp. has been found (Mendoza-Franco et al., 2012). In Pterygoplichthys disjunctivus, there is no information about its parasitic fauna in its native range. However, recent studies conducted outside its native range have documented the presence of the dactylogyrid monogenean $H$. heterotylus (Jogunoori, Kritsky \& Venkatanarasaiah, 2004) and the parasitic copepod Neoergasilus japonicus (Harada, 1930) in Okinawa, Japan (Nagasawa \& Uyeno, 2012; Nitta \& Nagasawa, 2013).

Out of the four species found in this study for $P$. pardalis, three of them (I. multifiliis, $U$. vaginoclastrum and Clinostomum sp.) had not been previously recorded, although their presence appears to be occasional, as they were found on a single individual. These parasites were likely acquired from native host species (Jogunoori et al., 2004).

Another interesting result of this study was the absence of gastrointestinal parasites in both invasive fish, which is likely because these introduced species have not yet acquired a parasitic fauna that could contribute to regulating their population growth in the invaded environment (Anderson, 1978). In this regard, other studies have also suggested that the low diversity of parasite species recorded in sailfin catfish species could be related to their distinctive, very thick shell that is filled with tiny thorns, which could be a barrier for some parasite species (Whittington et al., 2000). Apparently, the small number of years that these fish have been present in the new geographical range along with its feeding habits and behaviour (bentic algae/ weeds) seems to be a more probable explanation.
In the life cycle of trematodes of genus Clinostomum, their eggs are dispersed in the feces of fish-eating birds that usually are the definitive host. The egg gives rise to a miracidial covered with cilia that swim freely and infects a snail, resulting in a sporocyst that migrates to the intestine or liver of the host snail. Subsequently, through the food web this sporocyst is transmitted to a fish where it becomes metacercaria. The cycle is completed when a fish-eaten bird eats the fish (Olsen, 1986). In monogeneans, most species are oviparous. The ciliated larva that arises from the egg can swim and infect the only host of their life cycle. Only a few monogeneans are viviparous, among which highlight those belonging to the genus Gyrodactylus, in which until three generations can occur in a single host individual (Bakke et al., 2007). It is also known that this type of ectoparasites can be transmitted, even without direct contact whit an infected host, and some are so specific that when the host dies they are able to find a new host of the same species (Cable \& Harris, 2002). Regarding I. multifiliis, free-swimming theront stage parasites invade the skin and gills of host fish and rapidly transform into feeding trophonts within the epidermis (Cassidy-Hanley et al., 2011). Mature trophonts exit the host tissue, giving rise to the tomont stage. Then, tomonts attach to an inert support, encyst within a gelatinous capsule, and rapidly divide to give rise to 100-1000 new infective theronts within $18-24 \mathrm{~h}$ at $22^{\circ} \mathrm{C}$ (Cassidy-Hanley et al., 2011).

In this study, $H$. heterotylus was the most important parasite (in terms of prevalence and abundance) and the only one shared between both fish hosts. This parasite seems to be specific of loricarids (e.g. Nagasawa \& Uyeno, 2012; Nitta \& Nagasawa, 2013). The fact of not having found significant differences between them in the prevalence, intensity and abundance of this parasite between both hosts could be because these fish species share the same habitat, have similar behavior and food habits (Torchin et al., 2001).

Moreover, our data of prevalence, intensity and abundance of this monogenean (in both hosts) were consistent to those recorded inthe species of Heteropriapulus recorded in P. pardalis by Porto et al. (2012). In the case that these species of Heteropriapulus were the same, our results could indicate that the population characteristics of this parasite have been maintained, even outside its native range. Although to demonstrate it molecular studies are required.

On the other hand, monthly data of prevalence, intensity and abundance of this monogenean showed a similar temporal variability in both invasive fish. Also, a significant correlation was found (in both hosts) between the intensity and abundance of $H$. heterotylus and the water temperature, suggesting that intra-annual variability of this parasite is likely influenced by this environmental parameter, as has been documented in other parasite species (Chubb, 1977; Scott \& Nokes, 1984; Khidr, 2012). For example, a study conducted on Puntius spp. (Cyprinidae) from India revealed that abundance of monogeneans 
showed an increasing or decreasing trend with the rise and fall in temperature in general, although some monogenean species were more abundant during the monsoon and winter seasons (Shrivastava et al., 2012). Similarly, a previous study conducted within our study area revealed that the abundance of these loricariid species was higher from June to September and was positively correlated with the gonadosomatic index of these fish (Wakida-Kusunoki \& Amador-del Ángel, 2011). Therefore, it could be possible that the season of higher abundance of parasites is also related to the reproductive stage of the host, since it is well known that some fish species are more susceptible to parasite infection in periods of higher reproductive investment (Šimková et al., 2005).

Most parasite species recorded in this study have not been documented to be pathogenic to humans, although it is known that a species of Clinostomum (C. complanatum) has been found to infect humans (two in Korea and one in Japan) (Witenberg, 1944). This parasite was transmitted by eating raw or undercooked fish, which is linked to cultural factors of certain human populations (Park et al., 2009), and was found attached to the human mucous layer of larynx and pharynx. However, although the prevalence of these trematodes was very low in these hosts $(P$. pardalis and $P$. disjunctivus), it was not recommended to consume undercooked meat fish.

In summary, this study documents the parasite composition of the Amazon sailfin catfish species $P$. pardalis and $P$. disjunctivus, which are known to be highly invasive in many regions worldwide. In general, the parasite species richness was relatively poor (three species in $P$. pardalis and one in $P$. disjunctivus). Through this study, $P$. pardalis is assigned as new host for Clinostomum sp., I. multifiliis, $U$. vaginoclastrum and H. heterotylus and the study area as a new geographic location for the four species of parasites.

Finally, this research highlights the importance of conducting samplings in different seasons of the year in order to make a better characterization of the parasite fauna and to determine the environmental factors influencing its population dynamics.

\section{Acknowledgements}

We would like to thank Gomez-Ponce A., ÁlvarezGuillén $H$. and Reda-Deara A. for their help in field samplings. To Gerardo Perez-Ponce de León for providing materials and equipment in the Helminthology Laboratory at UNAM. Senior author thanks CONACyT (Consejo Nacional de Ciencia y Tecnología) and Instituto de Ciencias del Mar y Limnología, Universidad Nacional Autónoma de México (Mazatlán) for the Postdoctoral Fellow and support as well, as the two anonymous reviewers and the subject editor for their valuable suggestions. We are grateful to Karen Englander (Faculty of Languages, University of Baja California) for her English review and editing of manuscript.

\section{References}

Anderson, N. 1978. On the calculation of filter coefficients for maximum entropy spectral analysis. Pp. 252-255. In: D. G. Childers (Ed.). Modern Spectrum Analysis. New York, The Institute of Electrical and Electronics Engineers, IEEE Press.

Bakke, T. A., J. Cable \& P. D. Harris. 2007. The biology of gyrodactylid monogeneans: The "Russian-doll killers". Advances in Parasitology, 64: 161-376.

Bakke, T. A., P. A. Jansen \& L. P. Hansen. 1990. Differences in the host resistance of Atlantic salmon, Salmo salar L., stocks to the monogenean Gyrodactylus salaris Malmberg, 1957. Journal of Fish Biology, 37: 577-587.

Bush, A., K. D. Lafferty, J. M. Lotz \& A. W. Shostak. 1997. Parasitology meets ecology on its own terms: Margolis et al. revisited. Journal of Parasitology, 83: 575-583.

Bunkled-Williams, L., E. H. Williams Jr., C. G. Lilystrom, I. Corujo-Flores, A. J. Zerbi, C. Aliaume \& T. N. Churchill. 1994. The South American armored sailfin catfish Liposarcus multiradiatus (Hancock), a new exotic established in Puerto Rican fresh waters. Caribbean Journal of Sciences, 30: 90-94.

Cable, J. \& P. D. Harris. 2002. Gyrodactylid developmental biology: historical review, current status and future trends. International Journal of Parasitology, 32: 255-280.

Capps, K. 2008. The impacts of sailfish catfish (Siluriformes: Loridariidae) on invaded freshwater ecosystems. Abstracts of Annual Meeting of American Ichthyologist and Herpetologist Society. 23-28 July, Montreal, Canada.

Cassidy-Hanley, D. M., M. M. Cordonnier-Pratt, L. H. Pratt, C. Devine, M. M. Hossain, H. W. Dickerson \& T. G. Clark. 2011. Transcriptional profiling of stage specific gene expression in the parasitic ciliate Ichthyophthirius multifiliis. Molecular and Biochemical Parasitology, 178: 29-39.

Chaichana, R. \& S. Jongphadungkiet. 2012. Assessment of the invasive catfish Pterygoplichthys pardalis (Castelnau, 1855) in Thailand: ecological impacts and biological control alternatives. Tropical Zoology, 25: 173-182.

Chavez, J. M., R. M. De La Paz, S. K. Manohar, R. C. Pagulayan \& J. R. Carandang Jr. 2006. New Philippine record of South American sailfin catfishes (Pisces: Loricariidae). Zootaxa, 1109: 57-68.

Chubb, J.C. 1977. Seasonal occurrence of helminths in freshwater fishes. Part 1. Monogenea. Advances in Parasitology, 15: 133-199.

Cucherousset, J. \& J. D. Olden. 2011. Ecological impacts of nonnative freshwater fishes. Fisheries, 36: 215-230.

Fuller, P. L., L. G., Nico \& J. D, Williams. 1999. Nonindigenous fishes introduced into inland waters of the United States. American Fisheries Society Special Publication 27, Bethesda,American Fisheries Society, Pp. 435-441.

Gibbs, M. A., J. H. Shields, D. W. Lock, K. M. Talmadge \& T. M. Farell. 2008. Reproduction in an invasive exotic catfish Pterygoplichthys disjunctivus in Volusia Blue Spring, Florida, USA. Journal of Fish Biology, 73: 1562-1572.

Guzmán, A. F. \& S. J. Barragán. 1997. Presencia de bagres sudamericanos (Osteichthyes: Loricariidae) en el río Mezcala, Guerrero, México. Vertebrata Mexicana, 3: 1-4. 
Guzmán-Cornejo, C., L. García-Prieto, G. Rivas-Lechuga, B. Mendoza-Garfias, D. Osorio-Sarabia \& G. MontielParra (Eds.). 2012. Manual de prácticas para el estudio de metazoarios parásitos de vertebrados. México, D. F, Las prensas de Ciencias, Facultad de Ciencias, UNAM, 141 p.

Harris, P. D., J. Cable, R. C. Tinsley, \& C. M. Lazarus. 1999 Combined ribosomal DNA and morphological analysis of individual gyrodactylid monogeneans. The Journal of parasitology, 1999: 188-191.

Hill, A. M. \& D. M. Lodge. 1999. Replacement of resident crayfishes by an exotic crayfish: the roles of competition and predation. Journal of Applied Ecology, 9: 678-690.

Hossain, M. Y., M. M. Rahman, Z. F. Ahmed, J. Ohtomi \& A. B. M. S. Islam. 2008. First record of South America sailfin catfish Pterygoplichthys multiradiatus in Bangladesh. Journal of Applied Ichthyology, 24: 718-720.

Jogunoori, W., D. C. Kritsky \& J. Venkatanarasaiah. 2004. Neotropical Monogenoidea. Three new species from the gills of introduced aquarium fishes in India, the proposal of Heterotylus n. g. and Diaphorocleidus n. g., and the reassignment of some previously described species of Urocleidoides Mizelle and Price, 1964 (Polyonchoinea: Dactylogyridae). Systematic Parasitolology, 58: 115-124.

Kelly, D. W., R. A. Paterson, C. R. Townsend, R. Poulin, \& D. M. Tompkins. 2009. Has the introduction of brown trout altered disease patterns in native New Zealand fish? Freshwater Biology, 54: 1805-1818.

Keszka, S., R. Panicz \& A. Tanski. 2008. First record of the leopard pleco Pterygoplichthys gibbiceps (Actinopterygii: Loricariidae) in Brda river in the centre of Bydgoszcz (Northern Poland). Acta Ichthyologica Et Piscatoria, 38: 135-138.

Khidr, A. A. A., A. E. Said, O. A. Abu Samak \& S. E. Abu Sheref. 2012. The impacts of ecological factors on prevalence, mean intensity and seasonal changes of the monogenean gill parasite, Microcotyloides sp., infesting the Terapon puta fish inhabiting coastal region of Mediterranean Sea at Damietta region. The Journal of Basic \& Applied Zoology, 65: 109-115.

Levin, B. A., P. H. Phoung \& D. S. Pavlov. 2008. Discovery of the Amazon sailfin catfish Pterygoplichthys pardalis (Castelnau, 1855) (Teleostei: Loricariidae) in Vietnam. Journal of Applied Ichthyology, 24: 715-717.

Liang, S. H., L. C. Chuang \& M. H. Chuang. 2006. The pet trade as a source of invasive fish in Taiwan. Taiwania, 51: 93-98.

Liang, S. H., H. P. Wu \& B. S. Shieh. 2005. Size structure, reproductive phenology, and sex ratio of an exotic armored catfish (Liposarcus multiradiatus) in the Kaoping River of southern Taiwan. Zoological Studies, 44: 252-259.

Martínez-Palacios, C., C. Mendoza \& L. Ross. 2009. Tentative solutions to an alien species invasion from aquarium aquaculture: developing viable industries to exploit and control Pterygoplichthys multiradiatus Hancock 1828 in Mexico. [http://www.aqua.stir.ac.uk/GISAP/pdfs/Pterygo_ Istanbul.pdf. Date of access 22 June 2014].
Martorelli, S. R., P. S. Marcotegui \& P. Alda. 2008. Trichodina marplatensis sp. n. (Ciliophora: Trichodinidae) from Combjelly, Mnemiopsis mccradyi (Mayer, 1900) in Argentine Sea. Acta Protozoologica, 47: 257-261.

Mendoza-Franco, E. F., J. M. Caspeta-Mandujano \& SalgadoMaldonado, G. 2012. Primer reporte de Heteropriapulus sp. (Platelmintos, Monogenoidea) infectando al pez diablo Pterygoplichthys pardalis (Siluriformes, Loricariidae) introducido en la cuenca del Rio Lacantún de la Reserva de la Biosfera Montes Azules, Chiapas, México. Jaina Boletin Informativo, 23: 1-6.

Mendoza-Alfaro, R. E., P. Koleff-Osorio, C. Ramírez-Martínez, P. Álvarez-Torres, M. Arroyo-Damián, C. Escalera-Gallardo \& A. Orbe-Mendoza. 2011. La evaluación de riesgos por especies acuáticas exóticas invasoras: una visión compartida para Norteamérica. Ciencia Pesquera, 19: 65-75.

Nagasawa, K. \& D. Uyeno. 2012. Geographical distribution affected by the Kuroshio of the fish parasite Cymothoa pulchra (Isopoda: Cymothoidae) in Japanese waters. Biogeography, 14: 151-153.

Nitta, M. \& K. Nagasawa. 2013. First Japanese record of Heteropriapulus heterotylus (Monogenea: Dactylogyridae), from the alien catfish Pterygoplichthys disjunctivus (Siluriformes: Loricariidae) in Okinawa. Species Diversity, 18: 281-284.

Olsen, O. W. 1986. Animal parasites: their life cycles and ecology. Baltimore, University Park Press, 562 p.

Özdilek, S. Y. 2007. Possible threat for Middle East inland water: an exotic and invasive species, Pterygoplichthys disjunctivus (Weber, 1991) in Asi river, Turkey (Pisces: Loriicaridae). Journal of Fisheries and Aquatic Sciences, 24: 303-306.

Park, C. W., J. S. Kim, H. S. Joo \&J. Kim. 2009. A human case of Clinostomum complanatum infection in Korea. Korean Journal of Parasitology, 47: 401-404.

Piazzini, S., E. Lori, L. Favilli, S. Cianfanelli, S. Vanni \& G. Manganelli. 2010. A tropical fish community in thermal waters of southern Tuscany. Biological Invasions, 12: 2959-2965.

Porto, D. B., J. F. Vital, A. K. Souza, A. M. Morais, A. M. B. Varella \& J. C. Malta. 2012. Metazoários parasitos de Pterygoplichthys pardalis (Castelnau, 1855) (Siluriformes: Loricariidae) da Amazônia central, Brasil. Revista Brasileira Zoociência, 14: 35-40.

Poulin, R., R. A. Paterson, C. R. Townsend, D. M. Tompkins \& D. W. Kelly. 2011. Biological invasions and the dynamics of endemic diseases in freshwater ecosystems. Freshwater Biology, 56: 676-688.

Pound, K. L., W. H. Nowlin, D. G. Huffman \& T. H. Bonner. 2011. Trophic ecology of a nonnative population of suckermouth catfish (Hypostomus plecostomus) in a central Texas springfed stream. Environmental Biology of Fishes, 90: 277-285.

Rózsa, L., J. Reiczigel \& G. Majoros. 2000. Quantifying parasites in samples of hosts. The Journal of Parasitology, 86: 228-232.

Sandoval-Huerta, E. R., X. Madrigal-Guridi, A. García-Meraz, N. I. Dimas-Mora \& O. Domínguez-Domínguez. 2012. Nuevo registro de Pterygoplichthys disjunctivus (Actinopterygii: Loricariidae) en la desembocadura del río Coahuayana, 
Coahuayana, Michoacán, México. Revista Mexicana de Biodiversidad, 83: 294-297.

Scott, M. E. \& D. J. Nokes. 1984. Temperature-dependent reproduction and survival of Gyrodactylus bullatarudis (Monogenea) on guppies (Poecilia reticulata). Parasitology, 89: 221-228.

Shrivastava, R. R., G. G. Agrawal \& N. Agrawal. 2012. Seasonal variation in monogenoid abundance on Puntius sp. Research Journal of Biology, 2: 186-190.

Šimková, A., J. Jarkovský, B. Koubková, V. Baruš \& M. Prokeš. 2005. Associations between fish reproductive cycle and the dynamics of metazoan parasite infection. Parasitology Research, 95: 65-72.

Simonović, P., V. Nikolić \& S. Grujić. 2010. Amazon sailfin catfish Pterygoplichthys pardalis (Castelnau, 1855) (Loricariidae, Siluriformes), a new fish species recorded in the Serbian section of the Danube River. Biotechnology \& Biotechnological Equipment, 24: 655-660.

Sokal, R. R. \& F. J. Rohlf. 1995. Biometry: the principles and practice of statistics in biological research. New York, W. H. Freeman, 850p.

Steel, R. G. \& J. H. Torrie. 1986. Bioestadística: principios y procedimientos. México, McGraw-Hill, 620p.

Thatcher, V. E. \& A. B. Varella. 1981. Duas novas espécies de Megacoelium Szidat, 1954 (Trematoda: Haploporidae), parasitas estomacais de peixes da Amazônia Brasileira, com uma redefinição do gênero. Acta Amazonica, 11: 285-289.

Torchin, M. E., K. D. Lafferty, A. P. Dobson, V. J. McKenzie \& A. M. Kuris. 2003. Introduced species and their missing parasites. Nature, 421: 628-630.
Torchin, M. E., K. D. Lafferty \& A. M. Kuris. 2001. Release from parasites as natural enemies: increased performance of a globally introduced marine crab. Biological Invasions, 3: 333345.

Torchin, M. E. \& C. E. Mitchell. 2004. Parasites, pathogens, and invasions by plants and animals. Frontiers in Ecology and the Environment, 2: 183-190.

Wakida-Kusunoki, A \& E. Amador-del Ángel. 2011. Aspectos biológicos del pleco invasor Pterygoplichthys pardalis (Teleostei: Loricariidae) en el río Palizada, Campeche, México. Revista Mexicana de Biodiversidad, 82: 870-878.

Wakida-Kusunoki, A. T., R. Ruiz-Carus \& E. Amador-del Ángel. 2007. Amazon sailfin catfish, Pterygoplichthys pardalis (Castelnau, 1855) (Loricariidae), another exotic species established in southeastern Mexico. The Southwestern Naturalist, 52: 141-144.

Whittington, I. D., B. W. Cribb, T. E. Hamwood \& J. A. Halliday. 2000. Host-specificity of monogenean (platyhelminth) parasites: a role for anterior adhesive areas?. International Journal for Parasitology, 30: 305-320.

Witenberg, G. 1944. What is the cause of the parastic laryngopharyngitis in the near East "Halalzoun"? Acta Medica Oriental, 3: 191-192.

Zar, J. H. 1999. Biostatistical Analysis. Upper Saddle River, Pearson Prentice Hall, 663p.
Submitted April 20, 2016 Accepted May 27, 2016, by Jorge Eiras 